\title{
Originals
}

\section{Factors affecting and patterns of residual insulin secretion during the first year of Type 1 (insulin-dependent) diabetes mellitus in children}

\author{
E. B. Sochett, D.Daneman, C.Clarson and R.M.Ehrlich \\ Division of Endocrinology, Department of Pediatrics, The Hospital for Sick Children and University of Toronto, Toronto, Canada
}

\begin{abstract}
Summary. We measured serum C-peptide, glucose, $\mathrm{pH}$, islet antibodies and insulin antibody binding at diagnosis in 84 children with Type 1 (insulin-dependent) diabetes. In a subgroup of 33 children, residual insulin secretion (basal and peak C-peptide response to Sustacal), insulin antibody binding and $\mathrm{HbA}_{1 \mathrm{c}}$ were measured at 10 days, 1, 3, 6 and 12 months. At presentation C-peptide correlated positively with age at onset and negatively with the blood glucose concentration. Median C-peptide concentration at diagnosis was low, rose significantly $(p<0.05)$ at 10 days, reached a maximum at 1-3 months and declined gradually to 1 year. C-peptide concentration both at diagnosis and at 10 days correlated with that at 3 and 6 months. Of the factors investigated, only age $(p<0.005)$ and sex (higher in females, $p<0.01$ ) were found to have a significant influence on basal/peak Cpeptide levels throughout the first year. In particular there was no relationship between C-peptide, $\mathrm{HbA}_{1 \mathrm{c}}$ and insulin dose during this period. A peak C-peptide response at $3-6$ months $>/<0.32 \mathrm{nmol} / 1$ was used to divide the group
\end{abstract}

into two: 16 had a peak response $<0.32 \mathrm{nmol} / 1$ (low secretors) while in 17, the peak C-peptide was $>0.32 \mathrm{nmol} / 1$ (high secretors). While the low secretors had significantly $(p<0.05)$ lower $\mathrm{C}$-peptide levels during the first year, there were no differences between low and high secretors in $\mathrm{HbA}_{1 \mathrm{c}}$ or insulin dose. These data suggest that there are two patterns of residual insulin secretion during the first 12 months after diagnosis of Type 1 diabetes. One pattern shows good amplitude and duration of residual insulin secretion, while both these features are significantly $(p<0.05)$ reduced in the other. The C-peptide concentration both at diagnosis and at 10 days, as well as age at onset and sex are important predictors of the pattern to be followed. Our data suggest further that the magnitude of residual insulin secretion does not play a decisive role in metabolic control during this period.

Key words: C-peptide, residual insulin secretion, metabolic control, islet cell antibodies, islet cell surface antibodies, insulin antibody binding.
Many people with Type 1 diabetes experience a period of low insulin requirement and excellent metabolic control shortly after diagnosis and initiation of insulin therapy. This phase, known as the honeymoon period [1] or Brush effect has been presumed to be due to partial recovery of insulin secretion. Study of residual Bcell function during the honeymoon period was hampered initially by the lack of suitable methods for distinguishing exogenous from endogenous insulin.

This became feasible in the mid-1970s, however, with the development of a sensitive immunoassay for C-peptide [2] and the evidence that C-peptide, which is secreted in equimolar amounts with insulin from the B cell after cleavage of proinsulin, accurately reflects insulin secretion [3]. Residual B-cell function has since been studied in a number of ways: (a) as detectable C-peptide, (b) the C-peptide response under everyday conditions to a test meal or use of pharmacological agents (defined here as residual insulin secretion); and (c) the procedure outlined in (b) but preceded by a period of normoglycaemia (B-cell reserve). Much of our current understanding of residual B-cell function in Type 1 diabetes is based on large cross-sectional studies $[4,5]$ aimed primarily at determining the prevalence of residual B-cell function and its role in metabolic control $[6,7]$. Only a few prospective studies [8-10] have been published, and these have involved small numbers of patients.

A number of these studies have reported undetectable or very low levels of C-peptide at diagnosis [11], while others have found levels within the normal fasting range [8]. Within 2 weeks of diagnosis, there is a partial return of insulin secretion in the majority of patients. This recovery as reflected by basal and stimulated C-peptide concentrations reaches a maximum at 3-6 months and then gradually subsides [9]. The prevalence of residual B-cell function (defined as detectable C-peptide) at 2 years duration is approximately $100 \%$, 
Table 1. Clinical and biochemical features of the patient group $(n=84)$ at diagnosis

\begin{tabular}{lccc}
\hline & Mean & Median & $\begin{array}{l}\text { Interquartile } \\
\text { range }\end{array}$ \\
\hline $\begin{array}{l}\text { Age (years) } \\
\begin{array}{l}\text { Duration of } \\
\text { preceding symptoms } \\
\text { (weeks) }\end{array}\end{array}$ & 9.2 & 9.80 & 6.0 \\
$\begin{array}{l}\text { Glucose } \\
\text { (mmol/1) }\end{array}$ & 5.3 & 3.0 & 2.0 \\
$\begin{array}{l}\text { HCO } 3 \\
\text { (mmol/1) }\end{array}$ & 28.3 & 27.0 & 12.3 \\
pH & 19.9 & 23.35 & 11.25 \\
$\begin{array}{l}\text { C-peptide } \\
\text { (nmol/1) }\end{array}$ & 7.33 & 7.36 & 0.125 \\
\hline
\end{tabular}

but by 10 years has fallen to $15 \%$ [12]. Except for age at onset [12], no other features at diagnosis have been identified which will allow prediction of the quality (magnitude and duration) of residual B-cell function; younger children appear to produce less insulin for shorter periods than older children.

Recently there have been attempts to improve and prolong residual B-cell function by various immune therapies [13]. This approach has highlighted the dearth of C-peptide data during the first year against which the effect of these maneouvres should be measured. We therefore undertook to study the course of residual insulin secretion during the first year following diagnosis in conventionally treated children both to add to data currently available in the literature and to gain further insights into: (a) the relationship of $\mathrm{C}$ peptide to clinical and biochemical factors at presentation; (b) the factors at presentation which will allow prediction of the quality of residual insulin secretion; and (c) the relationship of residual insulin secretion to metabolic control during this period.

\section{Subjects and methods}

Since January 1984, we have obtained a blood specimen for measurement of serum glucose, electrolytes, $\mathrm{pH}, \mathrm{C}$-peptide, insulin antibody binding (IAB), islet cell antibodies (ICA) and islet cell surface antibodies (ICSA) from all children with newly diagnosed Type 1 diabetes prior to insulin therapy. From amongst this group we recruited those children who met the following criteria: (i) age 6-18 years and (ii) intended regular follow-up in the Diabetes Clinic at the Hospital for Sick Children, Toronto. To date we have determined baseline values at diagnosis in 84 children. Thirty-three of these children have completed at least 1 year, and form the basis of this report. The protocol was approved by the Human Experimentation Committee at the Hospital for Sick Children and consent obtained from all participants or their parents.

After discharge from hospital these children are followed by a multidisciplinary team, approximately monthly for the first 3 months and then every third month. All children in the study were managed on either once or twice daily injections of intermediate-acting bio- or semi-synthetic human insulin (Humulin N, Lilly Laboratories, Indi- anapolis, Ind, USA or Novolin Lente, Connaught-Novo, Toronto, Canada), with or without the addition of short-acting human insulin (Humulin R or Novolin Toronto). The frequency and dose of insulin were determined by the blood glucose results obtained initially in hospital and then at home with self monitoring of blood glucose. Our management goals have been outlined previously [14] and are similar to those practiced in most major centres.

\section{Protocol}

At 10 days, 1, 3, 6 and 12 months after diagnosis of Type 1 diabetes, a Sustacal stimulation test was carried out as previously described [15]. After an overnight fast and omission of the morning insulin, the subjects ingested Sustacal ( $7 \mathrm{ml} / \mathrm{kg}$ ) over 5-10 min. At time 0 (baseline pre-Sustacal) blood was drawn for measurement of glucose, Cpeptide, $\mathrm{IAB}$, and $\mathrm{HbA}_{1 \mathrm{c}}$ and again at 60 and $120 \mathrm{~min}$ post-Sustacal ingestion for glucose and C-peptide measurement.

\section{Methods}

Serum glucose was measured by a glucose oxidase method (Ektachem). $\mathrm{HbA}_{1 \mathrm{c}}$ was measured by a highly specific HPLC method, incorporating an acetate buffer incubation step for removal of the labile fraction of $\mathrm{HbA}_{1 \mathrm{c}}$ [16]. C-peptide was measured by radioimmunoassay using antiserum $\mathrm{M} 1230$ and ${ }^{125}$ I-labelled C-peptide obtained from Novo Laboratories, Bagsvaerd, Denmark [2]. The lower limit of detectability of this assay is $0.025 \mathrm{nmol} / 1$. Intra- and interassay coefficients of variation were $3.5 \%$ and $9.8 \%$ respectively $[15,17]$. ICA was measured by indirect immuno-fluorescence on group $0 \mathrm{hu}-$ man pancreas [18], and ICSA by ${ }^{51} \mathrm{Cr}$ release cytotoxicity [19]. IAB was measured by the method of Palmer et al. [20].

\section{Statistical analysis}

A normal distribution for non-normally distributed data (C-peptide, IAB, duration of symptoms) was obtained after $\log$ transformation (loge), and this transformed data was used in all statistical calculations. Multiple regression analysis was used to evaluate both the data at diagnosis and during the first year (a repeat measures design was included for the latter). Analysis of variance with a repeat measures design was used to assess the interrelationship of $\mathrm{HbA}_{1 \mathrm{c}}$, insulin dose and C-peptide. Logistic regression analysis was used to determine factors affecting the patterns of residual insulin secretion. Comparison of different groups was made by use of the Student's t-test for unpaired means. A multiple comparisons procedure was used for comparisons within groups.

\section{Results}

The clinical and biochemical features of the 84 children evaluated at diagnosis are indicated in Table 1. Because of the skewed distribution of some of the data, results have been expressed as mean, median and interquartile range (IQR). Age at onset ranged from 0.5-17.5 years, while duration of preceding symptoms varied between 1-52 weeks. At presentation there was also wide variability in all biochemical parameters: plasma glucose $14.7-77 \mathrm{mmol} / 1$; pH 6.97-7.45; plasma $\mathrm{HCO} 32.2-30 \mathrm{mmol} / \mathrm{l}$. Twenty-four children $(28.5 \%)$ presented in ketoacidosis, the remainder having ketonuria but no biochemical evidence of acidosis. 


\section{At diagnosis}

Median C-peptide concentration at diagnosis was $0.03 \mathrm{nmol} / 1$ (IQR 0.025) (Table 1). Concentrations were below the level of detectability of the assay in 24 $(29 \%)$ and $<0.1 \mathrm{nmol} / 1$ in $72(85 \%)$. Multiple linear regression analysis using $\mathrm{C}$-peptide at diagnosis as the dependent variable and sex, age at onset, duration of symptoms, blood glucose, $\mathrm{pH}$, bicarbonate, insulin autoantibodies and ICA/ICSA as the independent variables showed a highly significant correlation with age $(r=0.42, p<0.0001)$ and an inverse correlation with blood glucose $(r=-0.24, p<0.02)$. As indicated in Figure 1, the relationship between $\log C$-peptide and age of onset is best described as quadratic - that is non-increasing until age 7 , after which a linear increase with age is seen. When this analysis was repeated for the subgroup followed prospectively $(n=33)\left(\mathrm{HbA}_{1 \mathrm{c}}\right.$ at 10 days was included with the data at diagnosis), age $(p<0.05)$ and $\mathrm{HbA}_{1 \mathrm{c}}(p<0.01)$ were found to be significantly correlated. There was no difference in mean $\mathrm{C}$ peptide concentration between those in ketoacidosis $(\mathrm{pH}<7.35)$ and those with normal acid-base status. Similarly there was no difference in C-peptide at diagnosis between males and females, between ICA positive and negative children or between ICSA positive and negative children.

\section{Residual insulin secretion during the first year}

Figure 2 depicts the course of C-peptide secretion (basal/peak, upper panel), insulin dose (middle panel) and $\mathrm{HbA}_{1 \mathrm{c}}$ (lower panel) at each test over the first year for the 33 children followed prospectively. At 10 days after diagnosis both basal and peak C-peptide concentration (median, IQR for basal and peak: 0.11, 0.12 and 0.25 , $0.16 \mathrm{nmol} / 1$ respectively) were significantly higher than C-peptide at diagnosis $(p<0.05)$. All children showed an increase in C-peptide from diagnosis to 10 days; in none was basal C-peptide below the limits of assay detectability at 10 days. Basal and peak C-peptide concentrations reached a maximum at 1-3 months (median, IQR for basal and peak: 1 month, basal $0.23,0.16$, peak $0.48,0.4 ; 3$ months, $0.18,0.18,0.43,0.44 \mathrm{nmol} / 1$ ) and then declined gradually, although not significantly, to $0.08,0.15$ and $0.16,0.36 \mathrm{nmol} / 1$ respectively, at 1 year.

At each test interval we found a highly significant correlation between basal and peak C-peptide ( $r=$ $0.62-0.88, p<0.001)$. C-peptide at diagnosis correlated with basal C-peptide at both 3 and 6 months $(r=0.61$ and 0.43 respectively, $p<0.05$ ). In addition, basal Cpeptide at 10 days correlated with basal C-peptide at both 3 and 6 months $(r=0.78$ and 0.46 respectively, $p<0.01$ ); similarly peak C-peptide at 10 days correlated with peak C-peptide at both 3,6 and 12 months $(r=0.56,0.47$ and 0.49 respectively, $p<0.01)$. In each case the highest order correlation was found with $\mathrm{C}$ -

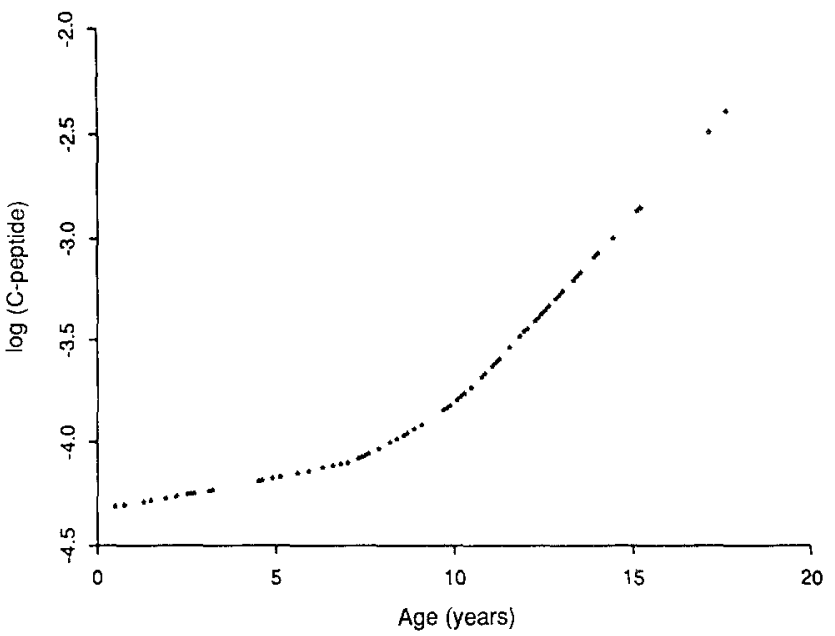

Fig.1. Relationship of C-peptide to age at onset at diagnosis $(n=84)$
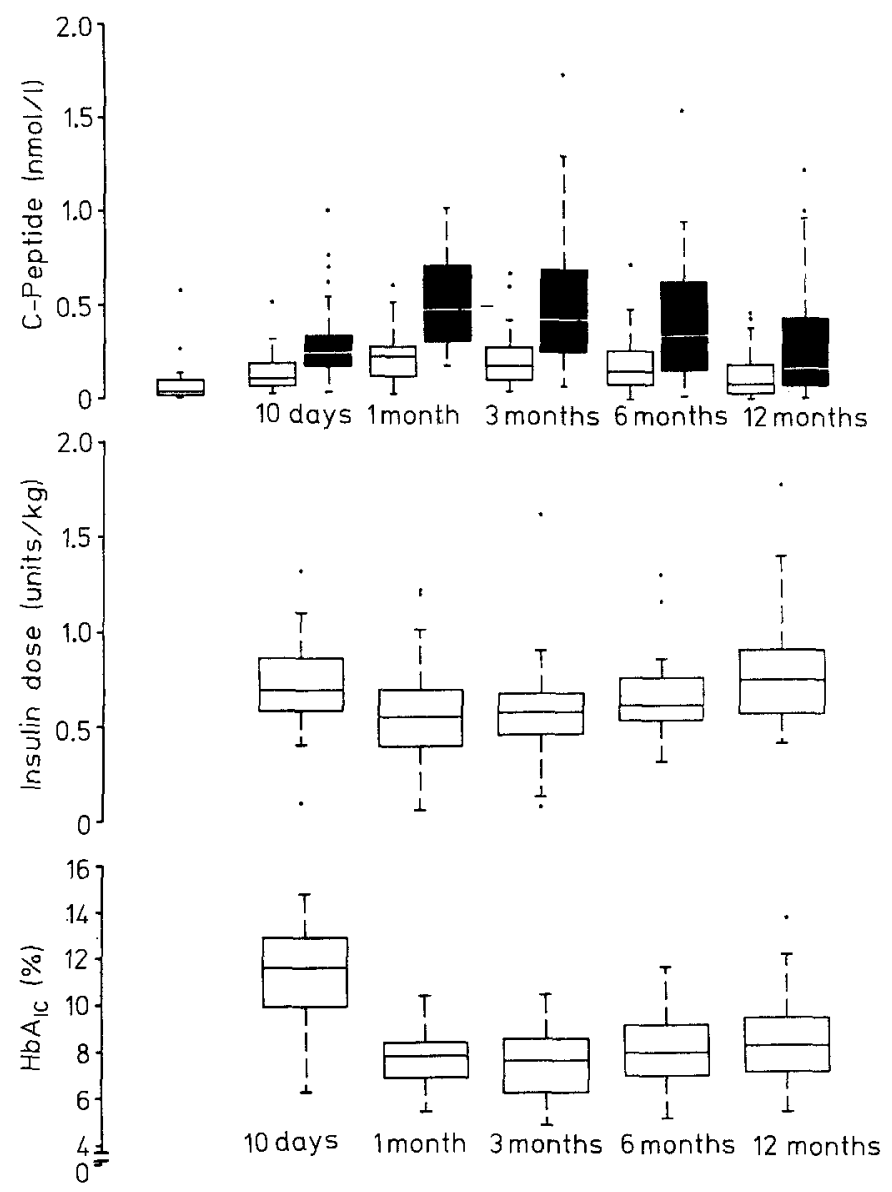

Fig. 2. C-peptide concentration (upper panel), insulin dose (middle) and $\mathrm{HbA}_{1 c}$ (lower) in the 33 Type 1 diabetic children followed prospectively. Results are expressed by the use of box plots. The horizontal line within the box locates the median, while the upper and lower ends of the box mark the 75 th and 25 th percentiles respectively. The interquartile range is defined by the vertical length of the box. The $T$ bars indicate the upper and lower adjacent values (observations closest to the inner fences, which are located at $1.5 \times$ interquartile range above and below the 75 th and 25 th percentiles respectively). In the upper panel, the open bars represent basal and shaded bars represent peak $\mathrm{C}$-peptide concentrations post-Sustacal ingestion 

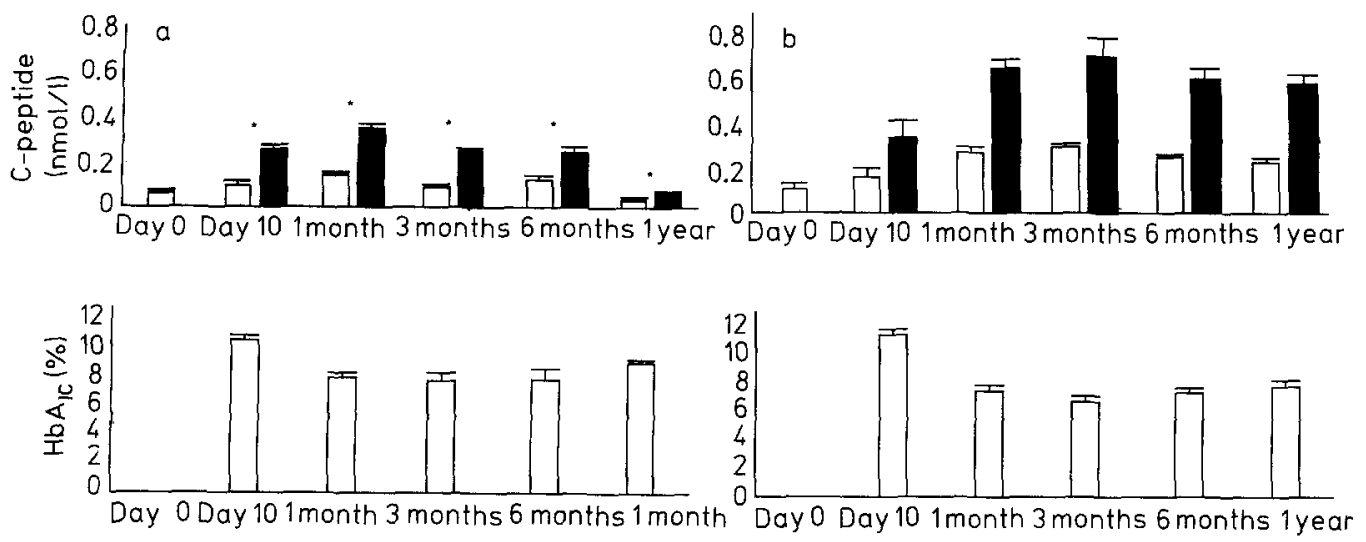

Fig. 3. C-peptide concentration (upper panel), $\mathrm{HbA}_{1 \mathrm{c}}$ (middle) and insulin dose (lower) in the 33 Type 1 diabetic children designated as either a) low secretors $(n=16)$ or b) high secretors $(n=17)$ during the first year after diagnosis. The results are expressed as mean \pm SEM. In the upper panel, the open bars represent basal and the shaded bars peak C-peptide concentrations post-Sustacal ingestion

Table 2. Comparison of the blood glucose responses following Sustacal ingestion in "low and high secretors"

\begin{tabular}{llcc}
\hline & & $\begin{array}{c}\text { "Low secretors" } \\
\text { blood glucose } \\
\text { (mmol/1) }\end{array}$ & $\begin{array}{c}\text { "High secretors" } \\
\text { blood glucose } \\
\text { (mmol/1) }\end{array}$ \\
\hline At diagnosis & 30.06 & 31.3 \\
10 days & Fasting & $9.95 \pm 1.98$ & $12.25 \pm 4.52$ \\
& 60 min & $17.69 \pm 4.2$ & $18.89 \pm 4.19$ \\
& 120 min & $17.20 \pm 3.96$ & $20.04 \pm 5.18$ \\
& AUC & $2038 \pm 450$ & $2282 \pm 603$ \\
1 month & Fasting & $9.97 \pm 4.00$ & $7.54 \pm 3.52$ \\
& 60 min & $17.12 \pm 4.87$ & $11.99 \pm 3.81^{\mathrm{b}}$ \\
& $120 \mathrm{~min}$ & $16.78 \pm 4.81$ & $11.77 \pm 4.06^{\mathrm{b}}$ \\
& AUC & $2022 \pm 619$ & $1405 \pm 498^{\mathrm{b}}$ \\
3 months & Fasting & $10.49 \pm 4.13$ & $9.86 \pm 3.9$ \\
& $60 \mathrm{~min}$ & $18.19 \pm 4.81$ & $14.74 \pm 4.59$ \\
& $120 \mathrm{~min}$ & $18.51 \pm 5.07$ & $14.36 \pm 4.47$ \\
& AUC & $2117 \pm 617$ & $1681 \pm 627$ \\
6 months & Fasting & $11.88 \pm 5.19$ & $11.00 \pm 4.35$ \\
& $60 \mathrm{~min}$ & $19.87 \pm 4.60$ & $16.28 \pm 5.08$ \\
& $120 \mathrm{~min}$ & $20.19 \pm 5.19$ & $16.71 \pm 6.07$ \\
& AUC & $2206 \pm 705$ & $1921 \pm 693$ \\
12 months & Fasting & $12.58 \pm 4.62$ & $10.36 \pm 4.68$ \\
& $60 \mathrm{~min}$ & $20.91 \pm 5.05$ & $16.84 \pm 6.04$ \\
& $120 \mathrm{~min}$ & $21.78 \pm 6.02$ & $17.19 \pm 6.13$ \\
& AUC & $2173 \pm 635$ & $1815 \pm 774$ \\
\hline
\end{tabular}

a AUC: area under the curve of glucose response; ${ }^{\mathrm{b}} p<0.01$. Results are expressed as mean $\pm \mathrm{SD}$

peptide concentrations at 3 months and declined thereafter. There was no correlation between basal C-peptide at 10 days and basal $C$-peptide at 12 months.

Mean $\mathrm{HbA}_{1 \mathrm{c}}$ fell significantly between 10 days and 1 month (11.4 $\mp 2.0 \%$ and $7.9 \pm 1.2 \%$, respectively, $p<$ $0.001)$. The nadir occurred at 3 months, corresponding to the highest basal and peak C-peptide concentrations. Between 3-12 months there was a gradual, although non-significant increase in $\mathrm{HbA}_{1 \mathrm{c}}$ (Fig. 2). The mean insulin dose decreased significantly between day 10 and 1 month $(0.72 \pm 0.25$ and $0.56 \pm 0.27 \mathrm{U} / \mathrm{kg}$, respectively, $p<0.05$ ). From 1-6 months, there was no statistical change in the mean insulin dose, but by 12 months this had increased to a level similar to that at 10 days $(0.78 \pm 0.30 \mathrm{U} / \mathrm{kg})$. There was a statistically significant increase in insulin dose $(p<0.05)$ between 3 and 12 months. Using analysis of variance, incorporating a repeat measures design, we found no relationship between $\mathrm{HbA}_{1 \mathrm{c}}$, C-peptide (basal/peak) and insulin dose from 1-12 months.

\section{Effect of clinical and biochemical parameters on residual insulin secretion}

We evaluated the relationship between C-peptide (basal/peak) over the first year and both the factors outlined at diagnosis (sex, age at onset, duration of symptoms, blood glucose, $\mathrm{pH}$, bicarbonate, IAB, ICS and ICSA) as well as those measured during the first year (blood glucose, $\mathrm{HbA}_{1 \mathrm{c}}$ and insulin dose) by multiple regression analysis with a repeat measures design. Only age at onset (basal C-peptide, $p<0.0005$; peak Cpeptide, $p<0.005$ ) and sex (basal C-peptide, $p<$ 0.0005 ; peak, $p<0.01$ ) (on average females were higher by $0.579 \mathrm{nmol} / 1$ ) were found to be significantly correlated.

\section{Low and high secretors}

Because individual C-peptide patterns appeared over the first year to separate into one of two categories (based on the peak C-peptide at 3-6 months, $<>$ 
$0.32 \mathrm{nmol} / 1$, maximum C-peptide) we chose also to divide our subjects into two groups using this cutoff (Fig.3). Mean basal and peak C-peptide were significantly lower at each test over the year in those whose maximum C-peptide was $<0.32 \mathrm{nmol} / 1$ at $3-6$ months (low secretors) compared to those whose maximum Cpeptide was above this level (high secretors) (all $p$ values $<0.05$ ). With the exception of the 1 month test, no differences were found when fasting, 60 , and $120 \mathrm{~min}$ blood glucose concentration and area under the curve of blood glucose were compared at each time interval between these two groups (Table 2). At 1 month the 60 and $120 \mathrm{~min}$ glucose concentrations and area under the glucose curve were significantly lower (all $p$ values $<0.01$ ) in the high secretors. The mean $\pm S D$ age of the low secretors was significantly lower than that of the high secretors $(10.0 \pm 2.1$ vs $13.5 \pm 2.1$ years, $p<0.001)$. There were no differences however in any of the tests with respect to $\mathrm{HbA}_{1 \mathrm{c}}$ or insulin dose.

\section{Discussion}

In this study we have found very low C-peptide concentrations at diagnosis in the majority of the children, and have documented a relationship between C-peptide at diagnosis and both age of onset of Type 1 diabetes and blood glucose concentration at presentation, but not with the duration of preceding symptoms. We also found no difference in C-peptide concentration between those presenting in ketoacidosis and those whose acid-base status was normal. These data would suggest that the insulin level at diagnosis is not the only determinant of clinical severity. It remains possible, however, that the severity of the metabolic disturbance relates directly to the duration of marked insulinopoenia. Further, children with normal acid-base status at presentation may have sufficient B-cell reserve despite low random levels to prevent metabolic decompensation.

C-peptide concentration at 10 days was significantly higher than at diagnosis, with all children showing some improvement in C-peptide secretion. It has been postulated that the reduction in blood sugar which follows insulin therapy, allows the surviving decompensated B cells time in which to regain responsiveness to changes in blood sugar and other stimuli [21]. The mechanism by which hyperglycaemia or the associated metabolic abnormalities pre-diagnosis inhibit insulin output from the residual B cells is unclear. The histological evidence of degranulation of $\mathrm{B}$ cells [22] seen shortly after diagnosis, and the inverse relationship between C-peptide at diagnosis and blood glucose supports the theory that chronic hyperglycaemia causes B-cell exhaustion. However, possible alterations in B-cell sensitivity or the effect of insulinopoenia itself need further investigation. Recovery of insulin secretion within the first 2 weeks of diagnosis is invariably incomplete. This is presumably a result of the absolute decrease in B-cell number [23] already established by the time of diagnosis. The short duration over which initial recovery occurs suggests that this is due to reversal of a functional component rather than to B-cell regeneration or to a diminution of the inflammatory response.

Maximum residual insulin secretion occurred in our children at 1-3 months, after which both basal and peak response to Sustacal gradually decreased. Review of individual responses over the 12 months suggested that there were two patterns of residual insulin secretion: approximately half the group had a low peak Cpeptide at 3-6 months, followed by very low basal and peak responses during the second 6 months, while the other half had a fairly good response at 3-6 months which was well sustained up to a year. This difference was confirmed statistically when the children were divided into two groups based on the peak C-peptide response at 3-6 months. These high and low secretors differed with respect to age but not to $\mathrm{HbA}_{1 \mathrm{c}}$ or insulin dose. This difference in C-peptide secretion between low and high secretors could not be attributed to a difference in glycaemic stimulus to the B cell. Nor could it be ascribed to a difference in glucose homeostasis, as similar fasting blood glucose and $\mathrm{HbA}_{1 c}$ concentrations were observed in both groups. It would appear that both groups were exposed to the same degree of abnormal glucose homeostasis and yet responded to a test meal in significantly different ways. Moreover logistic regression analysis showed that these two groups were determined largely, although not entirely, by age and sex.

The question remains as to whether these findings would have been confirmed had we measured C-peptide reserve rather than residual insulin secretion. Madsbad et al. [24] recently reported on two groups of Type 1 diabetic patients treated with either intensified or conventional insulin regimens for the first 18 months following diagnosis and found no difference in C-peptide secretion between them. This suggests that had we measured C-peptide reserve rather than residual insulin secretion, we would have observed similar results. By extension, the lack of a relationship between residual insulin secretion and $\mathrm{HbA}_{1 \mathrm{c}}$ and insulin dose would have been true also for C-peptide reserve. Taken together, these data suggest that a reciprocal relationship between C-peptide and blood glucose becomes most evident during periods of poor, and least evident during periods of tight or moderately good, glucose homeostasis.

In the conventionally treated Type 1 diabetic child, the response of the surviving $B$ cells to meals is almost always against the background of abnormal blood glucose homeostasis. It would seem that it is this response (which we have defined here as residual insulin secretion) rather than the response following a period of im- 
posed normoglycaemia (C-peptide reserve) that is metabolically significant. However, the role of residual insulin secretion in metabolic control remains unresolved. While a number of studies $[15,25,26]$ have found low order correlations in patients with long standing Type 1 diabetes between residual insulin secretion and metabolic control, others have not confirmed this [27]. Where a positive relationship has been found, reference is also made to individual patients in good metabolic control in the absence of residual insulin secretion and vice versa [15]. The inference drawn from this is that while significant residual insulin secretion may promote good metabolic control, the latter is still feasible in the absence of residual insulin secretion.

The interrelationship of residual insulin secretion and metabolic control has not been studied extensively during the first year after diagnosis of Type 1 diabetes. A few investigators have commented however on the apparent paradox during the honeymoon of excellent metabolic control in the face of declining insulin requirements and residual insulin secretion that either remains unchanged or is less than that seen shortly after diagnosis $[28,29]$. While there appears in our study to be a reciprocal relationship between residual insulin secretion and exogenous insulin dosage, this was not confirmed by multiple regression analysis.

It seems unlikely therefore that increased endogenous insulin secretion alone has resulted in decreased insulin requirements. Further, the absence of a relationship over the first year in our study between Cpeptide (basal/peak) and $\mathrm{HbA}_{1 \mathrm{c}}$ suggests that within the range of observed C-peptide responses, residual insulin secretion does not have a major impact on metabolic control $\left(\mathrm{HbA}_{1 \mathrm{c}}\right)$. Further evidence to support this point is derived from the comparison of low and high secretors. At each time interval there were significant differences in $\mathrm{C}$-peptide concentration between these two groups but no differences were found in $\mathrm{HbA}_{1 \mathrm{c}}$ or insulin dose.

These data support the concept that given some endogenous insulin secretion, insulin sensitivity and possibly other factors may be of greater significance in the course of the honeymoon period in children with Type 1 diabetes than the quantitative aspect of residual insulin secretion. This concept is further supported by the recent study of Yki-Järvinen and Koivisto [30] which demonstrated low insulin sensitivity 2 weeks after diagnosis of Type 1 diabetes followed by a transient normalisation at 3 months and subsequent decline at 1 year.

Other investigators have also examined the possibility that certain clinical or biochemical features at presentation might predict the future course of residual insulin secretion or partial clinical remission. Crosssectional data have shown age at onset to be a fairly reliable predictor of the prevalence and possibly of the magnitude of residual insulin secretion [31, 32]. In our study we have shown a significant influence of both age and sex on C-peptide (basal/peak) during the first year after diagnosis. Further the C-peptide concentration at diagnosis and at 10 days may be useful in predicting residual insulin secretion during the first year. However, none of the other factors examined at diagnosis (blood glucose, insulin autoantibodies, ICA ICSA, pH, bicarbonate) appeared to influence the quality of residual insulin secretion during the first year.

Two longitudinal studies have recently examined the relationship of islet cell antibodies to residual Bcell function. Marmer et al. [33] showed that children who remain persistently positive for ICA after diagnosis had a more rapid decline in fasting C-peptide during the second year than children who remain negative from diagnosis. Mustonen et al. [34] found no difference in integrated C-peptide over 24 months between children persistently positive and negative for ICA or complement fixing (CF) ICA from onset. However, there was a significant fall in C-peptide secretion during the second year in those CF-ICA positive children who became negative. The persistence/disappearance of ICA $/$ CF-ICA would appear therefore to have implications for residual B-cell function during the second but not the first year following diagnosis. In that we have not measured ICA status longitudinally, our data are not comparable. However, it is of interest that we too, using only ICA/ICSA status at diagnosis, were unable to find an effect on residual B-cell function during the first year.

In summary, we have demonstrated two patterns of residual insulin secretion during the first year of Type 1 diabetes in childhood. One pattern shows good amplitude and duration of residual insulin secretion, while both these features are significantly reduced in the other pattern. Our data suggest further that the magnitude of residual insulin secretion does not play a decisive role in metabolic control during the first 12 months after diagnosis of Type 1 diabetes in childhood. While this data and that from others lends support to a role for insulin sensitivity in the honeymoon period this needs to be confirmed. Continued follow-up of our patients is planned and may help provide an answer to the question of the effect of the magnitude of residual insulin secretion during the honeymoon period on the prevalence of both the short and long term complications of Type 1 diabetes.

Acknowledgements. We wish to thank Ms U. Manuel, R. N. and Ms M. McVey, R. N. for their role in carrying out the tests on the subjects, Dr. J.W. Yoon (University of Calgary) for kindly measuring ICA and ICSA, Ms P.Goodwin for secretarial support. We also thank Professor D. Andrews, Ms P. Brasher (Clinical Research Support Unit, University of Toronto) and Ms N. Fahrner for assistance with the statistical analysis. This study was supported by a grant from the Medical Research Council of Canada (MA-8172). Dr. Sochett was supported by fellowship grants from Medical Research Council (South Africa) and the Hospital for Sick Children Foundation and Dr. Clarson by the Hospital for Sick Children Foundation. 


\section{References}

1. Baker L, Kaye R, Root AW (1967) The early partial remission of juvenile diabetes mellitus. The roles of insulin and growth hormone. J Pediatr 71: 825-831

2. Heding LG (1975) Radioimmunological determination of human C-peptide in serum. Diabetologia 11: $541-548$

3. Horwitz DL, Starr JI, Mako ME, Blackard WG, Rubinstein AH (1975) Proinsulin, insulin and C-peptide concentrations in human portal and peripheral blood. J Clin Invest 55: 1278-1283

4. Ludvigsson L, Heding LG, Yarsson Y, Leander E (1977) C-peptide in juvenile diabetics beyond the post-initial remission period. Acta Paediatr Scand 66: 177-184

5. Hendrikson C, Faber OK, Drejer J, Binder C (1977) Prevalence of residual B-cell function in insulin-treated diabetics evaluated by plasma C-peptide response to intravenous glucagon. Diabetologia 13: 615-619

6. Gonen B, Goldman J, Baldwin O, Goldberg RB, Ryan WG, Blix PM, Schanzlin D, Fritz KJ, Rubenstein AH (1978) Metabolic control in diabetic patients: Effect of insulin secretory reserve and circulating insulin antibodies. Diabetes 28: 749-753

7. Binder C, Faber OK (1978) Residual B-cell function and its metabolic consequences. Diabetes 27: 226-229

8. Ludvigsson J, Heding LG (1978) Beta cell function in children with diabetes. Diabetes 27: 230-234

9. Madsbad S, Krarup T, Regeur L, Faber OK, Binder C (1980) Insulin secretory reserve in insulin dependent patients at the time of diagnosis and the first 180 days of insulin treatment. Acta Endocrinol 95: 359-363

10. Block MB, Rosenfield RL, Mako ME, Steiner DF, Rubenstein AH (1973) Sequential changes in B-cell function in insulin treated diabetic patients assessed by $\mathrm{C}$-peptide immunoreactivity. $\mathrm{N}$ Engl J Med 288: 1144-1148

11. Block MB, Mako ME, Steiner DF, Rubenstein AH (1972) Diabetic ketoacidosis: Evidence for C-peptide and proinsulin secretion following recovery. J Clin Endocrinol Metab 35: 402-406

12. Madsbad S (1983) Prevalence of residual B-cell function and its metabolic consequences in Type I diabetes. Diabetologia 24: $141-147$

13. Rabinowe SL, Eisenbarth GS (1984) Immunotherapy of Type I (insulin-dependent) diabetes mellitus. In: Andreani D, Di Mario U, Federlow KF, Heding LG (eds) Immunology in diabetes. Kimpton, London, pp 171-175

14. Daneman D, Ehrlich R (1984) Management of insulin-dependent diabetes mellitus in childhood. Med North Am 15: 1852-1859

15. Clarson C, Daneman D, Drash AL, Becker DJ, Ehrlich RM (1987) Residual B-cell function in children with IDDM: Reproducibility of testing and factors influencing insulin secretory reserve. Diabetes Care 10: 33-38

16. Ellis G, Diamandis EP, Giesbrecht EE, Daneman D, Allen LC (1984) An automated high pressure liguid-chromatographic assay for hemoglobin $\mathrm{A}_{1 \mathrm{c}}$. Clin Chem 30: 1746-1752

17. Bonser AM, Webb PG (1983) C-peptide measurement: methods and clinical utility. Crit Rev Clin Lab Sci 19: 297-352

18. Bottazo GF, Pujol-Borrell R, Doniach D (1981) Humoral and cellular immunity in diabetes mellitus. Clin Immunol Allergy 1: 139-159

19. Soderstrum WK, Freedman ZR, Lernmark A (1979) Complement dependent cytotoxic islet cell surface antibodies in insulin-dependent diabetes. Diabetes 28: 397

20. Palmer JP, Clemons P, Lyen K, Tatpati O, Raghu PK, Paquette
TL (1983) Insulin antibodies in insulin dependent diabetics before insulin treatment. Science 222: 1327-1330

21. Anderson A, Westman J, Hellerström C (1974) Effects of glucose on the ultrastructure and insulin biosynthesis of isolated mouse pancreatic islet maintained in tissue culture. Diabetologia 10: $743-753$

22. Gepts W, De Mey J (1978) Islet cell survival determined by morphology. An immunocytochemical study of the islet of Langerhans in juvenile diabetes mellitus. Diabetes 27: 251-261

23. Gepts W, Lecomple PM (1981) The pancreatic islets in diabetes. Am J Med 70: 105-113

24. Madsbad S, Edsberg B, Saurbrey N, Krarup T, Kühl C (1986) Effect of 1.5 years strict metabolic control on B-cell function in IDDM. Acta Endocrinol 112 (275): 15

25. Gerbitz K-D, Kemmler W, Edelman A, Summer J, Mehnert H, Wieland $\mathrm{OH}$ (1979) Free insulin, bound insulin, C-peptide and the metabolic control in juvenile onset diabetes: comparison of C-peptide secretors and now secretors during 24 hours conventional insulin therapy. Eur J Clin Invest 9: 475-483

26. Dalquist G, Blom L, Bolme P, Hagenfeld L, Ludvigsson F, Persson B, Thalme B, Theorell M, Westin S (1982) Metabolic control in 131 juvenile onset diabetic patients as measured by $\mathrm{HbA}_{1 c}$ : relation to age, duration, C-peptide, insulin dose and one or two insulin injections. Diabetes Care 5: 399-403

27. Mirel RD, Ginsberg-Fellner F, Horwitz DL, Rayfield EJ (1980) $\mathrm{C}$-peptide reserve in insulin dependent diabetes: comparative responses to glucose, glucagon and tolbutamide. Diabetologia 19: 183-188

28. Schober E, Schernthaner G, Frisch H, Fink M (1984) B-cell function recovery is not the only factor responsible for remission in Type I diabetics: evaluation of C-peptide secretion in diabetic children after first metabolic recompensation and at partial remission phase: J Endocrinol Invest 7: 507-512

29. Gerlis CP, Cartwright B, Owens D (1983) Increases in insulin sensitivity and production cause insulin dose reductions in the first year of Type I diabetes. Diabetes 32: 131 A

30. Yki-Järvinen H, Koivisto VA (1986) Natural course of insulin resistance in Type I diabetes. N Engl J Med 315: 224-230

31. Ludvigsson J, Heding LG (1976) C-peptide in children with juvenile diabetes. Diabetologia 12:627-630

32. Eff C, Faber OK, Deckert T (1978) Persistent insulin secretion assessed by plasma $\mathrm{C}$-peptide estimation in long term juvenile diabetics with low insulin requirement. Diabetologia 15: 169-172

33. Marner B, Agner T, Binder C, Lernmark A, Nerup J, PaulsenMandrup T, Walldorff S (1985) Increased reduction in fasting Cpeptide is associated with islet cell antibodies in Type 1 (insulindependent) diabetic patients. Diabetologia 28: 875-880

34. Mustonen A, Knip M, Huttunen N-P, Puukka R, Käär M-L, Åkerblom HK (1984) Evidence of delayed B-cell destruction in Type I (insulin-dependent) diabetic patients with persisting complement-fixing cytoplasmic islet cell antibodies. Diabetologia 27: 421-426

Received: 23 October 1986

and in revised form: 15 May 1987

Dr. D. Daneman

The Hospital for Sick Children

555 University Avenue

Toronto, Ontario M5G 1 X8

Canada 